\title{
PARTISIPASI MASYARAKAT DALAM PERENCANAAN DAN PENGANGGARAN APBD DI KABUPATEN BANGKALAN
}

\author{
Safi', Indien Winarwati, Erma Rusdiana \\ Fakultas Hukum Universitas Trunojoyo Madura \\ Email : syafikdidin@yahoo.co.id, indien_w@yahoo.com, ermarusdiana@ymail.com
}

\begin{abstract}
Background of this research is the rapid growth Bangkalan of the post-operational Suramadu bridge which have significant impact on increasing local income. Increased of local revenues must be increase the welfare of society, therefore development sourced from the budget should be oriented in various aspects leading to the nation's independence. Unfortunately, society is still not maximal to use of channels of participation in budgeting. This study uses legal research empirical or socio-legal research, interview and observation is used to obtain primary data in the form of public participation in the budgeting process in Bangkalan. The result of this research is interpretation about Bangkalan development is only on physical form, the Bangkalan society is not maximized in using the existing channels as participation in the preparation and budget planning.
\end{abstract}

Keywords: Participatory Budgeting, Regulatory Model Policy, Society, Budgets

\begin{abstract}
Abstrak
Penelitian ini dilatar belakangi berkembang pesatnya Bangkalan pasca operasionalisasi Jembatan Suramadu yang tentunya juga membawa dampak signifikan terhadap meningkatnya pendapatan daerahnya. Meningkatnya pendapatan daerah sudah seharusnya meningkatkan pula kesejahteraan masyarakatnya, oleh karena itu pembangunan yang bersumber dari APBD harus berorientasi dalam berbagai aspek menuju pada kemandirian bangsa. Sayangnya masyarakat masih belum maksimal menggunakan saluran partisipasi penganggaran. Penelitian ini menggunakan metode penelitian hukum empiris atau yang biasa di sebut sebagai sosio legal research, wawancara mendalam serta observasi digunakan untuk mendapatkan data primer berupa partisipasi masyarakat terhadap proses penganggaran di Kabupaten Bangkalan. Penelitian ini mendapatkan hasil bahwasanya masyarakat di Bangkalan masih memaknai pembangunan hanya dalam bentuk fisik, masyarakat belum maksimal dalam menggunakan saluran yang ada sebagai bentuk partisipasi dalam penyusunan dan perencanaan APBD.

Kata Kunci : Partisipatory Budgeting, Model Pengaturan Kebijakan, Masyarakat, APBD
\end{abstract}

\section{A. Pendahuluan}


Tingginya angka kemiskinan menunjukkan bahwa negara masih kurang optimal dalam upaya meningkatkan kesejahteraan rakyatnya. Program-program pemerintah untuk mengurangi angka kemiskinan senyatanya masih jauh dari yang di harapkan, mulai bantuan raskin, pendidikan gratis sampai jaminan kesehatan belum mampu membuat masyarakat berkehidupan lebih layak.

Minimnya dana sudah tidak lagi pantas untuk dijadikan alasan atas kegagalan dalam mensejahterakan rakyat, pemerintah mengemban amanat yang besar untuk mengalokasikan dananya bagi sektor publik secara proporsional. Akar masalah seringkali terletak pada mis alokasi dan mis manajemen dalam penganggaran pembangunan. Dana rakyat seringkali dialokasikan eksekutif dan legislatif untuk kebutuhan yang tidak sewajarnya.

Bangkalan sebagai kota yang berkembang pesat pasca operasionalisasi Jembatan Suramadu membawa dampak yang signifikan terhadap meningkatnya pendapatan daerahnya, hal ini berbanding terbalik dengan jumlah masyarakat miskin dari tahun ketahun yang terus mengalami peningkatan. Pada tahun 2012 jumlah masyarakat miskin meningkat sebanyak 2.583 keluarga. Total masyarakat miskin di Kabupaten Bangkalan saat ini mencapai 100.102 keluarga, jumlah ini berdasarkan hasil Pendataan Percepatan Perlindungan Sosial (PPLS) tahun 2011 dan penerima raskin alokasi bulan Juni-Desember tahun 2012. Untuk mengawal dan mengawasi transparansi serta akuntabilitas dalam pengelolaan maupun pertanggungjawaban Anggaran Pendapatan dan Belanja Daerah (selanjutnya di sebut sebagai APBD) pada rakyat tidak cukup dilakukan oleh DPRD. Untuk itu diperlukan model pengaturan hukum agar dapat mewujudkan hak-hak masyarakat Bangkalan dalam berpartisipasi menyusun dan merencanakan APBD yang pro rakyat.

APBD merupakan unsur penting dalam upaya pengembangan kapabilitas dan efektifitas pemerintah daerah dalam melaksanakan pembangunan daerah. APBD bisa digunakan sebagai alat untuk menentukan besaran pendapatan dan pengeluaran daerah. APBD seharusnya bisa menjadi jelmaan dari keinginan 
masyarakat daerah dalam pembangunan. Artinya semua tahapan yang dimulai dari perencanaan dan persiapan, pengesahan, implementasi dan pelaporan serta evaluasi APBD sebaiknya bersifat terbuka sehingga tuntutan dan kebutuhan publik menjadi bagian yang terintegrasi didalamnya. Konstitusi pasal 23 UUD 1945 mengamanahkan serta mengatur dengan jelas dan tegas bahwa rakyat berhak untuk ikut dalam penyusunan dan pengambilan keputusan Anggaran. Hal ini diperkuat dengan Undang-undang Keuangan Negara nomor 17 Tahun 2003 dan SEB Mendagri-Bappenas. Menciptakan orientasi anggaran ke arah kesejahteraan rakyat diperlukan penganggaran yang partisipatif (Participatory Budgeting). Participatory Budgeting (PB) adalah proses pembuatan kebijakan yang inovatif, dimana masyarakat dilibatkan secara langsung dalam pembuatan kebijakan. Serangkaian forum diselenggarakan sehingga masyarakat memiliki kesempatan untuk mengalokasikan sumber daya, membuat prioritas kebijakan, dan memonitor belanja publik yang diselenggarakan pemerintah. Sistem ini akan menjadi baik dan berkepastian apabila berkekuatan normatif, etis dan partisipatif. Berdasarkan latar belakang di atas, maka permasalahan yang timbul dalam situasi ini bahwasanya pola-pola perencanaan dan penyusunan APBD yang bottom up planning kenyataannya belum dilakukan secara maksimal oleh penyelenggara pemerintahan di daerah, untuk itu diperlukan gambaran realitas tingkat partisipasi khususnya di Kabupaten Bangkalan sebagai dasar penyusunan kebijakan berbasis penganggaran yang partisipatif.

\section{B. Metode Penelitian}

Jenis penelitian yang digunakan dalam mencapai tujuan pada penelitian ini adalah penelitian hukum empiris atau penelitian hukum non doktrinal disebut juga sebagai penelitian hukum sosiologis (sosio legal research) yang dalam penelitian ini menitikberatkan terhadap bekerjanya hukum dimasyarakat. (Sunggono,2002;43). Penelitian ini dilaksanakan dengan kegiatan lapangan yang berlokasi di wilayah Kabupaten Bangkalan meliputi 18 wilayah kecamatan, dan kegiatan pengkajian hukum akan dilakukan di laboratorium Fakultas Hukum 
Universitas Trunojoyo Madura. Sebagai sumber informasi atau informan kunci dari penelitian ini adalah pihak-pihak yang terlibat langsung dalam proses pengelolaan anggaran daerah. Untuk keperluan itu yang dapat dijadikan sebagai sumber informasi yaitu : Masyrakat Desa, Tokoh Formal maupun Informal, LSM. Hasil wawancara sebagai sumber data primer yang diperoleh akan di olah secara tematik sesuai dengan perumusan masalah untuk selanjutnya di lakukan analisis yuridis secara kualitatif menggunakan penalaran yang argumentatif. Sedangkan data sekunder diperoleh dari kantor-kantor pemerintahan mulai dari tingkat desa sampai Kabupaten, Kantor Perwakilan Rakyat/DPRD dan kantor LSM.

\section{Hasil Penelitian dan Pembahasan}

\section{Realisasi Penggunaan atau Alokasi Dana APBD di Kabupaten Bangkalan}

Menurut Rinusu \& Mastuti (2003:21), ada tiga hak warga terhadap APBD, yaitu hak untuk mendapatkan alokasi anggaran yang memadai sebagai upaya peningkatan kesejahteraan rakyat dan hak untuk terlibat dalam proses anggaran. Selain itu ada juga hak untuk mengontrol APBD dalam rangka untuk memastikan sejauh mana alokasi anggaran berpihak pada kepentingan rakyat, untuk memastikan dipangkasnya praktik korupsi, dan untuk mengontrol proses evaluasi guna menjamin agar temuan penyimpangan anggaran ditindaklanjuti. Demokratisasi anggaran yang berpihak kepada kepentingan publik maka partisipasi warga menjadi kebutuhan yang tidak bisa ditawar lagi ( Rinusu \& Mastuti dalam Bowo Sugiarto, 2010 : 158-162)

Salah satu bagian penting dari reformasi di bidang pengelolaan keuangan daerah adalah reformasi di bidang penganggaran yang berimplikasi pada struktur APBD. Dengan ditetapkannya PP No. 105 Tahun 2000 tentang Pengelolaan Keuangan Daerah, di awal bergulirnya era otonomi daerah, telah menandai adanya reformasi di dalam struktur APBD Di dalam perkembangan berikutnya, PP 105/2000 direvisi dengan PP 58/2005 guna menyesuaikan dengan paket undang-undang di bidang keuangan negara ( UU 17/2003, UU 
1/2004 dan UU 15/2004). Namun demikian, struktur APBD tidak mengalami perubahan lagi. Penjelasan pada bagian berikutnya mengacu pada PP 58/2005 dan peraturan penjabarannya yaitu Permendagri 13/2006 dan Permendagri 59/2007. Berdasarkan pasal 20, PP 58/2005, struktur APBD merupakan satu kesatuan yang terdiri dari:

a. pendapatan daerah;

b. belanja daerah; dan

c. pembiayaan daerah.

Hubungan dari ketiga komponen APBD di atas dapat digambarkan secara ringkas menjadi sebuah bangunan APBD seperti berikut ini.

\begin{tabular}{ll}
\hline Pendapatan & $\mathrm{Xxxx}$ \\
Belanja & $\mathrm{Xxxx}$ \\
Surplus (Defisit) & $\mathrm{Xxxx}$ \\
Pembiayaan (neto) & $\mathrm{Xxxx}$ \\
SiLPA/SiKPA & $\mathrm{Xxxx}$ \\
\hline
\end{tabular}

Sumber : Kemenkeu 2010

Alokasi atau penggunaan APBD terangkum dalam laporan realisasi yang masuk ke dalam komponen "belanja”. Belanja daerah meliputi semua pengeluaran dari rekening kas umum daerah yang mengurangi ekuitas dana, merupakan kewajiban daerah dalam satu tahun anggaran dan tidak akan diperoleh pembayarannya kembali oleh daerah. Pengklasifikasian belanja diatur sebagai berikut: belanja daerah dirinci menurut urusan pemerintahan daerah, organisasi, program, kegiatan, kelompok, jenis, obyek dan rincian obyek belanja. (Kemenkeu, 2013)

Belanja menurut kelompok belanja terdiri dari:

a. belanja tidak langsung; dan

b. belanja langsung. 
Belanja Tidak Langsung merupakan belanja yang tidak terkait secara langsung dengan pelaksanaan program dan kegiatan. Kelompok belanja tidak langsung dibagi menurut jenis belanja yang terdiri dari:
a. belanja pegawai;
b. bunga;
c. subsidi;
d. hibah;
e. bantuan sosial;
f. belanja bagi hasil;
g. bantuan keuangan; dan
h. belanja tidak terduga.

Kelompok belanja langsung merupakan belanja yang dianggarkan terkait secara langsung dengan pelaksanaan program dan kegiatan. Kelompok belanja langsung dari suatu kegiatan sebagaimana dimaksud dibagi menurut jenis belanja yang terdiri dari: (Kemenkeu, 2013)
a. belanja pegawai;
b. belanja barang dan jasa; dan
c. belanja modal.

Telaah terhadap peenggunaan atau alokasi dana APBD di Kabupaten Bangkalan tiga tahun terkahir cenderung mempunyai trend yang sama. Trend yang sama ini dapat dilihat dari realisasi anggaran berdasarkan programprogram yang di usulkan. Penjelasan realisasi belanja daerah di sampaikan oleh sekretaris BPKAD Kabupaten Bangkalan Bapak Arifin Canon, SE., MM., mulai tahun 2012-2014, sebagai berikut :

a. Tahun 2012

Untuk belanja daerah TA 2012 ditargetkan sebesar Rp.1.329.360.731.140,65,- direalisasi sebesar Rp.1.220.089.510.079,59,atau $91,78 \%$ dari target yang ditetapkan, sehingga terdapat sisa belanja 
sebesar Rp.109.271.221.061,06,- yang berasal dari realisasi belanja tidak langsung.

b. Tahun 2013

Untuk belanja daerah TA 2013 ditargetkan sebesar Rp.1.444.778.078.371,76,- direalisasi sebesar Rp.1.431.497.631.931,72,atau 99,08\% dari target yang ditetapkan, sehingga terdapat sisa belanja sebesar Rp.1.286.719.553.560, 04,- yang berasal dari realisasi belanja tidak langsung sebesar Rp.726.241.454.776,93,-, dan realisasi belanja langsung sebesar Rp. 705.256.177.154,79.

c. Tahun 2014

Uraian Belanja daerah berdasarkan hasil ringkasan perubahan APBD tahun anggaran 2014 adalah sebesar Rp. 1.672.108.519.639,60., yang terdiri dari belanja tidak langsung sebesar Rp. 862.054.281.865,05 dan belanja langsung sebesar Rp. 810.054.237.774,55.

Belanja daerah sebagai salah satu komponen struktur APBD merupakan bagian yang bisa di akses dan diupayakan untuk meningkatkan kesejahteraan masyarakat. Berpedoman pada realisasi anggaran belanja daerah di Kabupaten Bangkalan tiga tahun terakhir masih di dominasi oleh belanja pegawai yang cenderung menghabiskan lebih dari 50\% pendapatan daerah. Masyarakat sebagai bagian yang berhak atas pendapatan daerah sudah seharusnya menyadari dan mengupayakan untuk semaksimal mungkin menggunakan hakhaknya dalam berpartisipasi melalui saluran yang ada.

Merujuk Keputusan Menteri Dalam Negeri No. 29 Tahun 2002 yang terkait dengan partisipasi masyarakat secara tidak langsung ada dalam beberapa pasal, antara lain :

a. Pasal 17 ayat (1) menyebutkan bahwa penyusunan arah dan kebijakan umum APBD dilakukan oleh DPRD yang diawali dengan penjaringan. 
b. Pasal 22 ayat (4) dan ayat (5) yang menyebutkan bahwa DPRD wajib mensosialisasikan RAPBD kepada masyarakat sebelum disahkan dalam Peraturan Daerah dan masukan dari masyarakat atas RAPBD didokumentasikan dan dilampirkan pada Perda tentang APBD.

c. Pasal 91 ayat (3) dan (4) menyebutkan bahwa DPRD wajib mensosialisasikan rancangan peraturan daerah tentang perhitungan APBD kepada masyarakat untuk mendapatkan masukan, dan masukan masyarakat tersebut didokumentasikan dan dilampirkan pada Perda tersebut.

Regulasi terhadap kinerja DPRD seringkali hanya bermakna simbolis dan cenderung manipulatif, karena lebih ditujukan pada konstituen dan daerah anggota DPRD setempat.

\section{Faktor internal dan faktor eksternal yang mempengaruhi proses pengambilan keputusan kebijakan APBD di Kabupaten Bangkalan.}

Peta konsep perencanaan dan penganggaran APBD di daerah sudah pasti berpedoman pada aturan mengenai pengelolaan keuangan Negara dan aturan penjabaranya. Menjadi kewenangan pemerintah daerah untuk merencanakan dan menganggarkan APBD daerahnya, kepercayaan yang diberikan sebagai amanat UU ini sudah seharusnya diwujudkan dalam penyelenggraan pemerintahan yang bersih dan bebas korup sesuai dengan prinsip good governance.

Upaya menciptakan kinerja pemerintahan yang baik khususnya di bidang manajemen keuangan telah diupayakan pemerintah dengan dikelurkannya seperangkat regulasi. PP. 105 tahun 2000 tentang Pengelolaan dan pertanggungjawaban Keuangan Daerah dan PP. 108 tahun 2000 tentang Tata Cara Pertanggungjawaban Kepala Daerah, merupakan tonggak reformasi dalam perubahan pola menajemen keuangan pemerintahan daerah. (Arif Hidayat, 2011 :31) Penganggaran berbasis kinerja pada dasarnya merupakan pola penganggaran yang sangat komprehensif. Ia merupakan suatu 
sistem penganggaran yang mengutamakan upaya pencapaian hasil kerja (outcomes) dari perencanaan alokasi biaya (input) yang ditetapkan. Definisi ini mengandung konsekwensi bahwa setiap alokasi dana harus dapat diukur capaian output/outcomes yang hendak dicapai dan input yang telah ditetapkan. Dengan penerapan anggaran berbasis kinerja ini berarti tolak ukur keberhasilan tidak lagi hanya diukur dari tingkat pecapaian penyerapan dana seperti yang terjadi selama ini, tapi ditentukan dari target kinerja yang terukur. (Arif Hidayat, $2011:$ 31)

Menurut Sirajuddin dkk (2006:180- 182), satu aspek yang penting dalam perencanaan dan penganggaran adalah konsep penganggaran partisipatif yang belum banyak dikenal di sini. Beberapa gambaran singkat mengenai penganggaran partisipatif yang mestinya dilakukan oleh pemerintah daerah adalah sebagai berikut: (1) Penganggaran partisipatif di lingkungan pemerintah daerah merupakan instrumen untuk mengembangkan dan mewujudkan pemerintahan yang baik dan akuntabel; (2) Penganggaran partisipatif adalah berkaitan dengan penyediaan informasi anggaran yang dapat digunakan oleh masyarakat untuk mempengaruhi pengambilan keputusan penganggaran (pendapatan dan belanja daerah); (3) Informasi anggaran harus memenuhi prinsip-prinsip terpercaya, tepat waktu, mudah dipahami, kepemilikan, dan relevan serta mampu meningkatkan pemahaman (fiscal education program); (4) Merupakan proses untuk memfasilitasi pemerintah dalam pengalokasian sumber dana yang terbatas untuk memenuhi kebutuhan dana prioritas daerah; (5) Merupakan proses di mana stakeholders mempunyai peluang untuk mempengaruhi alokasi sumber dana publik dan prioritas sektoral; (6) Merupakan proses untuk mencapai akuntabilitas dan efektivitas penggunaan dana publik; (7) Ada formula ataupun konsentrasi tema yang disepakati untuk alokasi dana publik; (8) Dapat direncanakan secara bertahap (misalnya tahap pertama 30\%-50\% anggaran dilaksanakan secara partisipatif); (9) Ada 3 tahapan di mana penganggaran partisipatif 
dilakukan yaitu pada tahap perumusan dan analisis anggaran, monitoring pembelanjaan, pelacakan, dan monitoring atas pelayanan umum; (10) Ada identifikasi para stakeholders yang disertakan dalam konsultasi anggaran; (11) Merupakan proses di mana pelaku pembangunan membahas, menganalisis, memprioritaskan, dan memantau pengambilan keputusan berkaitan dengan pendapatan dan belanja daerah; (12) Kriteria alokasi anggaran disepakati oleh masyarakat sehingga penggunaan dana publik lebih tanggap terhadap kebutuhan; (13) Prosedur penganggaran transparan kepada publik; (14) Ada review dan evaluasi masyarakat terhadap pelaksanaan dan kinerja anggaran tahun lalu; (15) Ada institusi pemerintah daerah yang jelas untuk mengangani penganggaran partisipatif; (16) Ada kalender, struktur, dan pengorganisasian yang jelas untuk konsultasi masyarakat (Dalam Arif Hidayat, 2011 : 32).

Hasil penetapan APBD yang diputuskan dalam Peraturan Daerah tentang APBD Tahunan terbesar dipengaruhi oleh faktor internal (penyelenggara pemerintahan) terutama unsur eksekutif yang menyusun RAPBD dan DPRD sebagai korektor. Pelaksanaan fungsi perencanaan dan penganggaran oleh penyelenggara pemerintahan di Bangkalan berjalan sesuai norma yang ada, baik pihak eksekutif yang melibatkan organ pemerintah kabupaten (Sekretaris Daerah, Bappeda, BPKAD) yang bersinergi menjadi Tim Anggaran Eksekutif beserta alat kelengkapan DPRD yaitu Badan Anggaran Legislatif .

Perencanaan dan penganggaran oleh pemerintah daerah Kabupaten Bangkalan menjadi faktor internal yang paling dominan dalam membuat keputusan tentang RAPBD, semua usulan dan program di inisiasi pihak eksekutif yang didalamnya juga mempertimbangkan usulan masyarakat hasil jaring aspirasi, demikian juga DPRD sebagai korektor. Dengan demikian antara pemerintah daerah dan DPRD mempunyai hubungan fungsional yang kuat dalam membuat kebijakan pengelolaan keuangan di daerah, Kepala daerah yang mempunyai hak budgeting harus di pandang sama dengan DPRD sebagai korektor yang menyetujui atau menolak inisiatif rancangan Perda 


\section{APBD.}

Faktor publik dalam membuat keputusan perencanaan dan pengganggaran APBD berdasarkan aturan yang ada memang sangat sempit ruang geraknya. Masyarakat hanya dijaring aspirasinya akan tetapi tidak terlibat dalam keputusanya. Masyarakat di kabupaten Bangkalan umumnya masih mempunyai pola pikir yang dangkal terhadap fungsi partisipasi pembangunan di daerahnya sehingga kebutuhan masyarakat secara maksimal belum bisa terakomodir. Ekstrimya partisipasi masyarakat sebagai faktor yang mempengaruhi pengambilan keputusan tidak ada sama sekali, karena memang mereka tidak dilibatkan dalam pembuatan keputusan Perda APBD.

Siklus pengelolaan keuangan daerah terdiri dari tahapan-tahapan kegiatan yang terkait satu dengan lainnya, diawali dengan tahap perencanaan dan penganggaran, dilanjutkan dengan tahap pelaksanaan dan penatausahaan/akuntansi dan diakhiri dengan tahap pertanggungjawaban pelaksanaan anggaran kepada DPRD yang dinyatakan dalam bentuk laporan keuangan dan laporan kinerja.

Perencanaan dan penganggaran mungkin saja didefinisikan secara terpisah, perencanaan dapat diartikan sebagai suatu proses untuk menentukan tindakan masa depan yang tepat, melalui urutan pilihan, dengan memperhitungkan sumber daya yang tersedia. Dalam konteks perencanaan pembangunan pemerintahan, maka penyusunannya terutama berpedoman pada UU No. 25 Tahun 2004 tentang Sistem Perencanaan Pembangunan Nasional. Sementara itu, penganggaran dapat diartikan sebagai suatu proses untuk menyusun sebuah anggaran; dan anggaran (APBD) dapat diartikan sebagai rencana keuangan tahunan pemerintahan daerah yang dibahas dan disetujui bersama oleh pemerintah daerah dan DPRD, dan ditetapkan dengan peraturan daerah.

Sejak memasuki era otonomi daerah, pemerintah daerah telah menjalani dua periode implementasi peraturan pengelolaan keuangan daerah, yaitu: 
a. Periode PP 105/2000 dan Kepmendagri 29/2002 (periode sebelum keluarnya paket Undang-Undang di bidang Keuangan Negara);

b. Periode PP 58/2005 dan Permendagri 13/2006 jo. Permendagri 59/2007.

Proses penyusunan rancangan APBD secara garis besar meliputi langkahlangkah sebagai berikut:

a. Penyusunan Rencana Kerja Pemda

b. Penyusunan Kebijakan Umum Anggaran (KUA) dan Prioritas dan Plafon Anggaran Sementara (PPAS)

c. Pembahasan KUA dan PPAS oleh Pemda dengan DPRD

d. Penyusunan Surat Edaran Kepala Daerah tentang Pedoman Penyusunan RKA SKPD.

e. Penyusunan Rencana Kerja Anggaran (RKA SKPD dan RKA PPKD)

f. Penyusunan Rancangan APBD

Pasal 1, PP No. 58 Tahun 2005 mengatur bahwa pengelolaan keuangan daerah adalah keseluruhan kegiatan yang meliputi perencanaan, pelaksanaan, penatausahaan, pelaporan, pertanggungjawaban, dan pengawasan keuangan daerah. Aktivitas perencanaan dan penganggaran dapat dikatakan sebagai tahapan paling krusial dan kompleks dibandingkan dengan aktivitas lainnya di dalam konteks pengelolaan keuangan daerah. Hal ini bisa kita lihat dari beberapa alasan berikut ini: (Kemenkeu, 2013)

a. Perencanaan (termasuk penganggaran) merupakan tahap awal dari serangkaian aktivitas (siklus) pengelolaan keuangan daerah, sehingga apabila perencanaan yang dibuat tidak baik, misalnya program/kegiatan yang direncanakan tidak tepat sasaran, maka kita tidak dapat mengharapkan suatu keluaran ataupun hasil yang baik/tepat sasaran.

b. Perencanaan melibatkan aspirasi semua pihak pemangku kepentingan pembangunan (stakeholders) baik masyarakat, pemerintah daerah itu sendiri dan pemerintah yang lebih tinggi (propinsi dan pusat) yang dilakukan melalui forum musyawarah perencanaan pembangunan 
(musrenbang) mulai dari tingkat kelurahan/desa, dilanjutkan di tingkat kecamatan, tingkat kabupaten/kota, sampai di tingkat propinsi dan nasional untuk menyerasikan antara perencanaan pemerintah kabupaten/kota/propinsi dan pemerintah pusat (perencanaan nasional).

c. Perencanaan Daerah disusun dalam spektrum jangka panjang (20 tahun) yang disebut RPJPD (Rencana Pembangunan Jangka Panjang Daerah); jangka menengah (5 tahun) yang disebut RPJMD (Rencana Pembangunan Jangka Menengah Daerah); dan jangka pendek (satu tahun) yang disebut RKPD (Rencana Kerja Pembangunan Daerah).

d. Penyusunan APBD harus dibahas bersama oleh pemerintah daerah dengan DPRD dan setelah disetujui bersama kemudian harus dievaluasi oleh pemerintah yang lebih tinggi (pemerintah propinsi/pemerintah pusat c.q. Menteri Dalam Negeri).

e. Anggaran mempunyai fungsi otorisasi, perencanaan, pengawasan, alokasi, distribusi, dan stabilisasi.

Setelah tahap perencanaan dan penganggaran selesai dilaksanakan, tahap berikutnya merupakan domain pemerintah daerah selaku eksekutif, yaitu tahap pelaksanaan, penatausahaan, dan pengawasan dan akhirnya ditutup dengan tahap pertanggungjawaban. Kesimpulannya adalah bahwa semua tahap dalam siklus pengelolaan keuangan daerah saling terkait erat dan setiap tahap tentunya memegang peranan penting dalam menyukseskan pengelolaan keuangan daerah yang efisien, efektif, transparan dan akuntabel.

3. Realitas Partisipasi Dalam Perencanaan dan Penganggaran di Kabupaten Bangkalan

Musrenbang yang dilakukan di seluruh kecamatan di Kabupaten Bangkalan adalah agenda tetap tahunan siklus kinerja Bappeda sebagai upaya menjaring aspirasi masyarakat seperti yang diamanatkan dalam Surat Edaran Bersama Menteri Negara Perencanaan Pembangunan Nasional dan Menteri Dalam Negeri Nomor 0295/M.PPN/I/2005, 050/166/SJ tahun 2005. 
Pengamatan tim peneliti dilapangan menunjukkan bahwa proses partisipasi masyarakat dalam perencanaan dan penganggaran di Kabupaten Bangkalan tidak seutuhnya optimal dan maksimal berbasis pada kebutuhan masyarakat. Walaupun secara normatif pihak eksekutif sudah menjalankan proses penjaringan kebutuhan masyarakat sesuai dengan yang diamanatkan oleh aturan yang ada, akan tetapi kegiatan ini hanya menjadi tahapan atau proses yang belum di manfaatkan secara maksimal oleh masyarakat Bangkalan. Tidak optimal ini di buktikan dengan usulan-usulan program selama ini hanya bersifat fisik dan hampir tidak ada pembangunan yang sifatnya pengembangan di bidang non fisik. Sebenarnya berbicara program non fisik, perencanaan oleh SKPD di Kabupaten Bangkalan juga mengarah pada pengembangan dan penguatan pembangunan sumber daya manusia akan tetapi sifatnya terbatas, berbeda kalau program ini di usulkan langsung oleh Desa yang membutuhkan.

Pelaksanaan musrenbang baik di tingkat desa sampai Kabupaten berdasarkan SKB Menteri Negara Perencanaan Pembangunan Nasional dan Menteri Dalam Negeri Nomor 0295/M.PPN/I/2005, 050/166/SJ tahun 2005, memang tidak mengatur secara tegas terhadap pihak yang bisa mengikuti tahapan musrenbang sebagai representasi partisipasi masyarakat, sehinggga pola yang berjalan di Bangkalan ada desa yang mengundang seluas luasnya masyarakat ada juga yang memanfaatkan kelembagaan yang ada sebagai wujud keterwakilan yaitu RT, RW, PKK, BPD dan aparatur di tingkat desa.

Kepala Badan Perencanaan Pembangunan Daerah Bangkalan, Bapak Ir. H. Tamar Djaja, MM., menyatakan bahwa pihak pemerintah daerah sudah menyediakan sedemikian rupa saluran partisipasi dalam perencanaan pembangunan, seluruh program dan tahapan menurut Ka. Bappeda sudah berjalan dengan baik. Musrenbang yang dilakukan di tingkat desa sampai kabupaten akan di jadikan dasar oleh tim anggaran dalam perencanaan dan penganggaran APBD setiap tahunnya. 
Partisipasi masyarakat dalam perencanaan dan penganggaran berdasarkan peraturan yang ada berakhir di musrenbang baik di tingkat desa sampai Kabupaten kemudian di formulasikan dalam RKPD. Masyarakat tidak lagi mempunyai kesempatan sampai pada proses pengesahan, meskipun ada tahapan Publick Hearing. Ka. Bappeda Kabupaten Bangkalan menyampaikan masyarakat masih berkesempatan menghadiri rapat paripurna pembahasan RAPBD antara eksekutif dan legislatif akan tetapi sifatnya hanya mendengar dan melihat karena kewenangan ada pada tim anggaran eksekutif dan tim anggaran legislatif.

Hal-hal yang menyebabkan tidak maksimal partisipasi masyarakat di Kabupaten Bangkalan dalam proses perencanaan dan penganggaran antara lain :

a. Pola pikir (Mindset) masyarakat di Bangkalan yang menganggap bahwa pembangunan yang bersumber dari APBD adalah bersifat fisik, padahal kebutuhan masyarakat saat ini tidak hanya berupa infrasruktur, akan tetapi harus dibangun pemikiran membangun dan menggali potensi sumber daya yang ada baik manusia maupun alamnya untuk program kemandirian dan pengentasan kemiskinan.

b. Tidak tegasnya mekanisme partisipasi masyarakat dalam Surat Edaran Bersama Menteri Negara Perencanaan Pembangunan Nasional dan Menteri Dalam Negeri Nomor 0295/M.PPN/I/2005, 050/166/SJ tahun 2005 menyebabkan pola tahapan musrenbang di Kabupaten Bangkalan baik di tingkat desa maupun Kabupaten berbeda beda, di desa satu dan desa lain ada yang mengoptimalkan warganya untuk mengusulkan program tetapi ada juga yang hanya mengandalkan kelembagaan yang ada di desa. Dalam hal ini partisipasi ada yang berbentuk terbuka bagi semua pihak ada pula yang bersifat keterwakilan.

c. Partisipasi masyarakat dalam proses perencanaan dan penganggaran APBD di Bangkalan mengacu pada aturan yang ada diformulasikan dalam RKPD 
yang merupakan kewenangan eksekutif dan belum menjadi hasil perencanaan dan penganggaran yang tetap/fix, karena ada beberapa tahapan lagi yang harus dilalui, hal ini berpotensi tidak disetujuinya usulan masyarakat berbasis kebutuhan.

d. Meskipun pihak legislatif di DPRD berkesempatan untuk menjaring aspirasi masyarakat akan tetapi sifatnya merupakan kegiatan pribadi dan hanya menjadi materi pembahasan dalam fraksi maupun komisi sebelum rapat paripurna anggaran dengan pihak eksekutif, realitasnya penjaringan dilakukan diwilayah keterwakilan anggota dan terhadap konstituennya saja, model partisipasi yang terbungkus dalam makna keterwakilan ini juga kurang optimal karena hanya melibatkan lokalitas dan hubungan emosional anggota dengan wilayah dan konstituennya, yang tidak memperhatikan kebutuhan masyarakat lain.

Makna partisipasi bagi masyarakat di Bangkalan berdasarkan kondisi realitas yang ada adalah "bahwa masyarakat terlibat dalam pengusulan pembangunan yang menurut mereka di wujudkan dalam pembangunan fisik dan saluran partisipasi itu bisa dilakukan sendiri sebagai warga atau keterwakilan melalui lembaga desa yang ada”. Pola pikir yang seperti ini harus di rubah sebagai bentuk kepedulian dan tanggungjawab Pemerintah Daerah terhadap hak-hak warga Negara untuk menikmati dalam kedudukannya di dalam pemerintahan maupun dalam pembangunan, bahwa masyarakat memiliki hak untuk berpartisipasi secara aktif dalam berbagai bentuk hak dan kemampuannya dalam pemerintahan. Hak konstitusional ini di atur menurut :

a. Pasal 27 ayat (1) UUD 1945, bahwa "Segala warganegara bersamaan kedudukannya di dalam hukum dan pemerintahan dan wajib menjunjung hukum dan pemerintahan itu dengan tidak ada kecualinya.” Pasal 28 ayat (2) bahwa "setiap orang berhak untuk memajukan dirinya dalam 
memperjuangkan haknya secara kolektif untuk membangun masyarakat, bangsa, dan negaranya."

b. Pasal 28F disebutkan bahwa "setiap orang berhak untuk berkomunikasi dan memperoleh informasi untuk pengembangan pribadi dan lingkungan sosialnya, serta berhak untuk mencari, memperoleh, memiliki, menyimpan dan mengolah, serta menyampaikan informasi dengan menggunakan segala jenis saluran yang tersedia.”

Regulasi diperlukan untuk meningkatkan partisipasi masyarakat di Kabupaten Bangkalan melaui Kebijakan oleh Pemerintah Daerah Kabupaten Bangkalan sebagai upaya perlindungan masyarakat Bangkalan sesuai dengan Pasal 27 ayat (1) dan Pasal 28F UUD 1945.

\section{Simpulan}

1. Jaring aspirasi masyarakat dalam pelaksanaan musrenbang baik di tingkat desa sampai Kabupaten di Bangkalan berdasarkan SKB Menteri Negara Perencanaan Pembangunan Nasional dan Menteri Dalam Negeri Nomor 0295/M.PPN/I/2005, 050/166/SJ tahun 2005 tahapannya sudah berjalan sesuai norma yang ada, akan tetapi saluran aspirasi ini tidak berfungsi maksimal karena pola pikir masyarakat pada umumnya terhadap APBD hanya berkisar seputar pembangunan fisik. Mekanisme jaring aspirasi di Kabupaten Bangkalan dalam musrenbang tidak mengatur subyek sebagai sumber partisipan pembangunan apakah terbuka untuk umum atau keterwakilan saja (melalui kelembagaan baik yang bersifat formal maupun swadaya masyarakat).

2. Keterwakilan masyarakat oleh DPRD Bangkalan seharusnya bisa dioptimalkan sesuai dengan fungsi legislatif dalam perencanaan dan penganggaran APBD meskipun melakukan jaring aspirasi sebagai bahan pembahasan di tingkat fraksi dan komisi akan tetapi hanya kepada daerah dan konstituen anggota. Alokasi belanja daerah di Kabupaten Bangkalan terbanyak diserap oleh belanja pegawai dan ini juga dipengaruhi dominsasi 
faktor internal yaitu penyelenggara pemerintahan di daerah, kondisi ini tercipta karena masyarakat tidak mempunyai kewenangan dalam mengawal perencanaan dan penganggaran ini sampai pada putusan dalam bentuk Perda APBN.

3. Upaya yuridis dalam bentuk kebijakan-kebijakan untuk mewujudkan partisipasi masyarakat dalam proses perencanaan penganggaran urgen untuk dilakukan, agar masyarakat mempunyai kesempatan yang berkekuatan dan berkepastian hukum untuk mengawal penganggaran yang pro rakyat.

\section{E. Persantunan}

Penulis Ucapkan terima kasih kepada Dit Litabmas Dikti TA 2014. Penelitian ini merupakan bagian dari laporan hasil tahun 1 penelitian hibah bersaing program Dit.Litabmas Dikti TA 2014 dengan judul asli “Participatory Budgeting Sebagai Dasar Penyusunan Model Kebijakan Partisipasi Masyarakat dalam Perencanaan dan Penganggaran APBD di Kabupaten Bangkalan”.

\section{DAFTAR PUSTAKA}

Arif Hidayat. 2011. Analisis Politik Hukum Partisipasi Masyarakat dalam Sistem Penganggaran

Daerah di Indonesia Pasca Reformasi. Jurnal Hukum Pandecta. Volume 6. Nomor 1. Januari.

Bowo Sugiarto. 2010. Keterbatasan Ruang Keterlibatan Warga dalam Penyusunan APBD.

Jurnal MKP Unair. Volume 25 Nomor 2

Sunggono, Bambang. 1998. Metodologi Penelitian Hukum. Jakarta. PT. Raja Grafindo

Persada

Kementerian Keuangan Dirjen Perimbangan Keuangan, Perencanaan dan Penganggaran, Materi Pelatihan Bagi Peserta Kursus Keuangan Daerah, Edisi Tahun 2013 
UU No. 32 Tahun 2004 tentang Pemerintahan Daerah

UU No. 33 Tahun 2004 tentang Perimbangan Keuangan Pemerintah Pusat dan Daerah

UU No. 25 Tahun 2004 tentang Sistem Perencanaan Pembangunan Nasional

UU No. 17 Tahun 2003 tentang Keuangan Negara

Surat Edaran Bersama Kepala Bappenas dan Menteri Dalam Negeri No. 1354/M. PPN/03/2004050/744/SJ Tahun 2005 tentang Pedoman Pelaksanaan Musrenbang dan Perencanaan Partisipanif Daerah 